there is a four-year cycle, centred on the lemming, in the numbers of mammals and birds on the arctic tundra; a four-year cycle, centred on the vole, in the adjacent open forest; and a ten-year cycle, centred on the Varying hare, in the forests of North America. The graphs representing the size of the population of these species regularly rise to a peak followed by a deep trough. There seems to be no reason for believing that man is subject to biological laws different from those affecting the other animals ; the human population of the world has been rising for many years-it has not yet reached its peak, but inevitably it will. The slope of the curve becomes ever steeper, not owing to man's fecundity, which has always been great, but owing to his control of the environment by his great engineering works to improve agriculture, and by his deliberate activities to improve production and reduce mortality through such organizations as the Food and Agriculture Organization and the World Health Organization. The crash is bound to come, and the human population, just like animal populations, is rapidly producing the means of its own destruction-it is possible and, according to some opinion, even probable that he has already contaminated his environment with artificial radioactive substances sufficiently to endanger his survival. There is only one means of escape, if indeed it is not already too late, and that is by devising ways of preventing the birth of unwanted numbers, rather than slaughtering them by mass destruction after they have been brought into the world. The surface of the earth is finite, and the amount of food that it can produce is limited; but long before the limit is reached the human population problem will have been solved-one way or the other.

Dr. Lack's interesting and stimulating book gives these matters only a brief mention in his last paragraph, but the whole of the preceding pages leading up to it makes it quite plain that in spite of religious, political and other prejudices and inhibitions, man is going the same way that all animal populations go when the birth-and death-rates do not balance: if he does not wish to increase the latter, he must control and decrease the former.

L. Harrison Mațthews

\section{ADMINISTRATIVE MEDICINE}

\section{Administrative Medicine}

Transactions of the Second Conference, December 8, 9 and 10, 1953. Edited by George S. Stevenson. Pp. 164. (New York: Josiah Macy, Jr., Foundation, 1954.) 3 dollars.

$\mathrm{B}$ ELIEVING that there is "a considerable obstruction to communication and mutual understanding across the disciplines and specialties" and that this is one of the major factors delaying scientific advancement, the Josiah Macy, Jr., Foundation arranges a series of annual conferences in which participates a small group of investigators representing, so far as possible, all the branches of science related to $a$ chosen programme. The aim is to keep the meetings as informal as possible and to encourage the exchange of methods, research plans, concepts and difficulties ; the informal nature and termpo of the discussion are preserved in the published transactions. The second programme on administrative medicine included a study of major components of administrative medicine, home-care programmes and the health services of the Department of Health for Scotland. This conference was attended by twenty-four persons, authorities on differing aspects of administrative medicine-university professors, public health service chiefs, hospital directors, directors of nursing services, directors of health insurance plans, directors of security departments of industrial firms, directors of research programmes, etc. Sir Andrew Davidson, then chief medical officer of the Department of Health for Scotland, was one of the guests.

Summarizing the proceedings of the conference, the chairman, Prof. H. R. Leavell, professor of public health practice at Harvard University, said it had emerged that administrative process has several phases : the recognition that a problem exists; definition of the problem and planning to meet it; development of a strategy of control ; performance ; and analysis or evaluation. Different types of administrators may be required to deal with each of these phases, though occasionally the necessary qualities may be found in a single (exceptional) individual. Team-work is important.

The personal qualifications of the administrator were discussed, and it was decided that he should be a good mixer, have a sense of humour and a sense of proportion, enthusiasm for his job, a special kind of motivation, and the kind of vision which enables him to visualize and project (perhaps less for certain phases of the administrative process than for others). In addition, he must have training to help him to do his job more effectively, a knowledge of the problem with which he is dealing, a eapacity for realizing when he should seek advice, the ability to organize technical personnel and equipment and to relate them to the people to be served; and enough judgment to gauge the probability of success.

T. Ferguson

\section{FREEDOM AND AUTHORITY}

Freedom and Control in Modern Society

Edited by Prof. Morroe Berger, Prof. Theodore Abel and Prof. Charles H. Page. (The Van Nostrand Series in Sociology.) Pp. xii +326. (New York: D. Van Nostrand Company, Inc.; London: Macmillan and Co., Ltd., 1954.) 45s. net.

$T$

HE fourteen essays comprising this book discuss those problems of individual freedom in an age of large-scale organization, of group relations and the relation of the individual to his government, which have engaged the interest and work of Robert M. MacIver. Further, the essays are written by scholars who admired MacIver, or who have been his students or colleagues; two of them, those by David Spitz and by Harry Alpert, respectively, attempt to evaluate Prof. MacIver's contribution to political and to sociological theory, the former including an appreciation of his theory of political obligation and the way in which MacIver's elaboration of this theory suggests that, within a democracy, means can be found of respecting the ultimate value of personality consistent with the maintenance of the social order.

The remaining essays range over such topics as friendship as a social process, the problem of authority, the political process in trade unions, social groups in the modern world, social structure and goals in group 